\title{
Copper balance, bone mineralization and the growth performance of turkeys fed diet with two types of $\mathrm{Cu}$ supplements
}

\author{
D. Mikulski ${ }^{1,3}$, J. Jankowski ${ }^{1}$, Z. Zduńczyk ${ }^{2}$, M. Wróblewska² \\ and M. Mikulska ${ }^{1}$ \\ ${ }^{1}$ Warmia and Mazury University, Department of Poultry Science \\ Oczapowskiego 5, 10-718 Olsztyn, Poland \\ ${ }^{2}$ Institute of Animal Reproduction and Food Research, Polish Academy of Sciences \\ Tuwima 10, 10-747 Olsztyn, Poland
}

(Received 6 October 2008; revised version 21 April 2009; accepted 6 November 2009)

\begin{abstract}
The aim of this study was to examine the effect supplementation of diet with $20 \mathrm{mg} \mathrm{Cu} / \mathrm{kg}$ from copper sulphate ( $\mathrm{Cu}-\mathrm{SUL})$ and/or copper amino acid chelate (Cu-AA) on the copper balance, bone mineralization status and growth performance of turkeys. A total of 840 one-day-old heavy Large White BIG-6 turkey males were randomly assigned to 4 groups: $\mathrm{Cu}-0, \mathrm{Cu}-\mathrm{SUL}, \mathrm{Cu}-\mathrm{SUL} /$ $\mathrm{Cu}-\mathrm{AA}$ and $\mathrm{Cu}-\mathrm{AA}$. The results of the present study confirm the $\mathrm{Cu}$-requirements for growing/ fattening turkeys given by scientific bodies (e.g., NRC, INRA, GfE). The $\mathrm{Cu}$ unsupplemented basal diet contained $11.3 \mathrm{mg} \mathrm{Cu} / \mathrm{kg}$ is enough for turkeys and further $\mathrm{Cu}$-supplementations are not necessary. Further supplementations from inorganic and/or organic sources did not significantly improve turkeys performance and health. Plasma superoxide dismutase activity, physico-chemical properties of bone and the concentrations of $\mathrm{Ca}$ and $\mathrm{P}$ in the tibial bone were generally not affected by dietary treatment. Further $\mathrm{Cu}$ supplementation from inorganic and/or organic sources increase the $\mathrm{Cu}$-excretion (from 808 to $1915-2164 \mathrm{mg}$ per animal) and may cause additional environmental problems.
\end{abstract}

KEY WORDS: copper, chelate, bone mineralization, performance, turkeys

\footnotetext{
${ }^{3}$ Corresponding author: e-mail: dariusz.mikulski@uwm.edu.pl
} 


\section{INTRODUCTION}

Copper is an essential mineral required for proper bone growth and development as well as enzyme function. In a number of enzymes and proteins, the role of $\mathrm{Cu}$ has been defined for many physiological functions related mostly to a catalytic agent in the active sites of cuproenzymes (McDowell, 1992). Copper supplementation is very important to maintain normal functions of the cardiovascular system in animals (Savage et al., 1966).

Copper sulphate was included as a $\mathrm{Cu}$ source as it is the typical form used by the poultry industry. Inorganic $\mathrm{Cu}$ in the form of $\mathrm{Cu}$-sulphate pentahydrate $\left(\mathrm{CuSO}_{4} \cdot 5 \mathrm{H}_{2} \mathrm{O}\right)$ is most commonly used as a dietary supplement for animals due to cost and commercial availability. Additional $\mathrm{Cu}$ sources have become available recently, and the potential for commercial use as feed additives has expanded. Many authors share the opinion that the excretion of trace elements can be reduced by dietary inclusion of low doses of readily available minerals. Several researchers (Hemken et al., 1993; Du et al., 1996) confirm that metal chelates of amino acids and peptides can enhance the bioavailability of trace elements. An important function of chelated and complexed metals is the extent to which organic ligands remain associated with the metal ligand under physiological conditions (Guo et al., 2001). Some commercially available chelated and complexed $\mathrm{Cu}$ compounds are purported to protect the mineral from becoming degraded or complexed with other compounds until the product reaches the section of the gastrointestinal tract where absorption occurs. The target site for these $\mathrm{Cu}$ products is the small intestine, and more specifically the duodenum which is the major site of absorption of minerals in chickens (Hurwitz and Bar, 1965).

In studies conducted by Guo et al. (2001) the bioavailability of several organic copper products for chickens was significantly greater than that of copper sulphate. When $\mathrm{Cu}$ sulphate was assigned a value of $100 \%$ as the standard, linear regression slope ratios of $\log _{10}$ liver $\mathrm{Cu}$ concentration regressed on added dietary $\mathrm{Cu}$ concentration gave estimated relative bioavailability values of 124, 122 and $111 \%$ for $\mathrm{Cu}$ lysine complex, $\mathrm{Cu}$ amino acid chelate and $\mathrm{Cu}$ proteinate, respectively. The bioavailability estimates for $\mathrm{Cu}$ lysine complex and $\mathrm{Cu}$ amino acid chelate were greater $(\mathrm{P} \leq 0.05)$ than that for $\mathrm{Cu}$ sulphate (Guo et al., 2001). Aoyagi and Baker (1993) reported that the relative bioavailability of $\mathrm{Cu}$ in a Lysine-Cu complex was $126 \%$ compared with $100 \%$ for that in copper sulphate.

NRC (1994) requirements of $\mathrm{Cu}$ for broiler chickens and turkeys is only 8 $\mathrm{mg} / \mathrm{kg}$. According to European Commission Health (SCAN, 2003) the copper content of diets for animals should not exceed $35 \mathrm{mg} / \mathrm{kg}$ feed, including up to $20 \mathrm{mg} \mathrm{Cu} / \mathrm{kg}$ feed from cupric chelate of amino acid hydrate. Information on the effectiveness of organic copper sources in turkey diets is scant. Therefore, the aim 
of this study was to examine the effect of practical wheat/soyabean meal-based diets supplemented with $20 \mathrm{mg} \mathrm{Cu} / \mathrm{kg}$ feed from copper amino acid chelate on the copper balance, bone mineralization status and growth performance of turkeys. In this study copper sulphate was used as a reference point for comparing the effectiveness of $\mathrm{Cu}$ amino acid chelate.

\section{MATERIAL AND METHODS}

\section{Animals and diets}

The experiment was conducted according to the guidelines of the Local Animal Experimentation Ethics Committee. A total of 840 one-day-old heavy Large White BIG-6 turkey males, sexed at the local commercial hatchery, were used. The initial body weight (BW) of day-old poults was $61 \mathrm{~g}$. Rearing was conducted to 126 days of age, according to the technology recommended by the British United Turkeys Company (B.U.T., 2002).

Each of the experimental diets consisted of a wheat-soyabean meal based basal diet formulated using least-cost linear programming software to meet the nutrient requirements of turkeys, according to B.U.T. (2002) recommendations. The composition and calculated nutritive value of basal mixtures are presented in Table 1. The birds were fed ad libitum, according to 4-step program, i.e. starter diet (1-28 days), grower 1 diet (29-56 days), grower 2 diet (57- 84 days) and finisher diet ( 85 to 126 days). Starter diets were offered as crumbles and the other diets - as $3 \mathrm{~mm}$ pellets. The diets contained no growth promoters or coccidiostatics. Pelleted feed was supplied by a local commercial animal feed mill. Fresh feed and water were provided daily and were available ad libitum.

Each of the 4 dietary treatments consisted of 7 replicate pens with 30 birds in each pen. The treatment diets were as follows: 1 . basal diet ( $\mathrm{Cu}-0$, no $\mathrm{Cu}$ source), 2. basal diet with $20 \mathrm{ppm} \mathrm{Cu}$ from $\mathrm{CuSO}_{4}(\mathrm{Cu}-\mathrm{SUL}), 3$. basal diet with a blend of $10 \mathrm{ppm} \mathrm{Cu}$ from $\mathrm{CuSO}_{4}$ and $10 \mathrm{ppm} \mathrm{Cu}$ from copper amino acid chelate (Cu-SUL/ AA), 4. basal diet with $20 \mathrm{ppm} \mathrm{Cu}$ from copper amino acid chelate ( $\mathrm{Cu}-\mathrm{AA})$. The diets were supplemented with elemental $\mathrm{Cu}$ as $\mathrm{CuSO}_{4}\left(\mathrm{CuSO}_{4} \cdot 5 \mathrm{H}_{2} \mathrm{O}\right.$; Merck Ltd.) or as $\mathrm{Cu}$-amino acid chelate (as Albion Copper Amino Acid Chelate supplied by Albion Laborat. Inc., France). Tested products were incorporated in the vitaminmineral premixes which was supplied by the Polsanders Co. (Pruszcz Gdański, Poland). 
Table 1. Composition $\left(\mathrm{g} / \mathrm{kg}^{-1}\right)$ and calculated nutrient content of the basal diets fed to turkeys from 1 to 126 days of age

\begin{tabular}{|c|c|c|c|c|}
\hline \multirow{2}{*}{ Item } & Starter 1 & Grower 1 & Grower 2 & Finisher \\
\hline & 1 to $28 \mathrm{~d}$ & 29 to $56 \mathrm{~d}$ & 57 to $84 \mathrm{~d}$ & 85 to $126 \mathrm{~d}$ \\
\hline \multicolumn{5}{|l|}{ Ingredient } \\
\hline wheat & 243.2 & 279.0 & 370.4 & 459.0 \\
\hline maize & 200.0 & 200.0 & 200.0 & 200.0 \\
\hline potato protein & 50.0 & 30.0 & - & - \\
\hline soyabean meal (46\%) & 423.0 & 403.0 & 341.0 & 253.0 \\
\hline soyabean oil & 33.0 & 20.0 & 21.0 & 24.0 \\
\hline animal fat & - & 25.0 & 30.0 & 30.0 \\
\hline limestone & 14.7 & 11.7 & 9.8 & 8.6 \\
\hline monocalcium phosphate & 19.8 & 15.2 & 11.4 & 9.7 \\
\hline salt & 2.6 & 2.1 & 1.5 & 1.5 \\
\hline $\mathrm{NaHCO}_{3}$ & 1.5 & 1.5 & 1.5 & 1.5 \\
\hline DL-methionine 99 & 1.6 & 1.3 & 1.0 & 0.8 \\
\hline L-lysine $\mathrm{HCl}$ & 0.6 & 1.2 & 2.3 & 1.1 \\
\hline L-threonine & - & - & 0.1 & 0.8 \\
\hline vitamin-mineral premix ${ }^{1}$ & 10.0 & 10.0 & 10.0 & 10.0 \\
\hline \multicolumn{5}{|l|}{ Calculated analyses } \\
\hline $\mathrm{ME}, \mathrm{kcal} / \mathrm{kg}$ & 2800 & 2900 & 3000 & 3100 \\
\hline crude protein, $\%$ & 28.00 & 26.01 & 22.02 & 19.00 \\
\hline lysine, $\%$ & 1.61 & 1.51 & 1.30 & 1.00 \\
\hline Met + Cys, $\%$ & 1.05 & 0.95 & 0.80 & 0.70 \\
\hline $\mathrm{Ca}, \%$ & 1.20 & 1.00 & 0.85 & 0.75 \\
\hline available $\mathrm{P}, \%$ & 0.60 & 0.50 & 0.42 & 0.38 \\
\hline $\mathrm{Na}, \%$ & 0.17 & 0.15 & 0.12 & 0.12 \\
\hline $\begin{array}{l}\text { supplied per kg of feed, IU: } \\
10 \text {, vit. } \mathrm{B}_{6} 6 \text {, vit. } \mathrm{B}_{12} 0.03 \text {, fo } \\
600, \mathrm{Mn}_{150} \text { from magnesi } \\
\text { from ethylene diamine dihy }\end{array}$ & $\begin{array}{l}5000, \text { vit } \\
\text { d } 2 \text {, biotir } \\
\text { ide, Zn } 90 \\
\text { ide, Se } 0.3\end{array}$ & 00; mg: vit. & $\begin{array}{l}\text { vit. } \mathrm{K}_{3} 2.5 \text {, } \\
\text { pantotheni } \\
0 \text { from ferro } \\
\text { Co } 0.2 \text {; g: C }\end{array}$ & $\begin{array}{l}\mathrm{B}_{1} 3.5, \text { vit. B } \\
\text { id } 21 \text {, cholin } \\
\text { ulphate, J } 1 . \\
.72\end{array}$ \\
\hline
\end{tabular}

\section{Animals managament}

The poults were vaccinated against turkey rhinotracheitis (TRT) by spray application at $1 \mathrm{~d}$ of age and were allocated at random to 28 pens with straw as bedding material. Stocking density was approximately $50 \mathrm{~kg} \mathrm{BW/}$ $\mathrm{m}^{2}$ of usable floor space in all pens. Visual health inspection of all birds was performed on a daily basis. Brooder rings for poults (till 10 days of age) and additional heat sources (till 28 days of age) were installed in the pens. Heating was provided by a central heating system and electric heaters (red light). The brooder unit's temperature was set at $35^{\circ} \mathrm{C}$ and then altered as needed to suit bird comfort. Room temperature was set at $28^{\circ} \mathrm{C}$ on the day of placement, and was subsequently reduced by $2^{\circ} \mathrm{C}$ per week. Temperature and humidity were recorded on a daily basis at $8 \mathrm{a} . \mathrm{m}$. and $3 \mathrm{p} . \mathrm{m}$. The lighting programme in the room was as follows: $23 \mathrm{~h}$ light at about 100 lux till 3 days of age and $14 \mathrm{~h}$ light at 5-6 
lux from day 4 until the end of the experiment. Relative humidity was about 65 to $70 \%$. Air changes were $0.4-0.5 \mathrm{~m}^{3} / \mathrm{h} / \mathrm{kg}$ BW from 2 to 7 weeks of age and $7-8 \mathrm{~m}^{3} / \mathrm{h} / \mathrm{kg}$ BW from 8 weeks of age.

Body weight and feed consumption were recorded on 28, 56, 84 and 126 day of age. Culling and mortality rates (specifying the cause of death and reason for rejection) were monitored on a regular basis. The cases and incidence of aortic rupture were recorded systematically.

\section{Cu balance, superoxide dismutase activity, bone mineralization status}

Copper balance was determined from day 25 to 29. At 21 days of age, ten birds were selected randomly of each treatment ( 5 replications, each of 2 birds) and transferred to individual cages for balance trials. Battery cages were thermostatically controlled, and turkeys had free access to water from nipple drinkers. After a three-day adaptation period (25th day of age), the birds were fasted for $14 \mathrm{~h}$, next they received a starter diet (administered in the growth performance test) $a d$ libitum for 5 days, and then they were fasted again for $14 \mathrm{~h}$. During the proper experimental period (5 days) feed intake was monitored on a regular basis, and excreta were collected. After removal of the non-faecal material, the excreta were stored in plastic bags at $-20^{\circ} \mathrm{C}$. After the collection period the moisture content of the excreta was determined by drying in a ventilated drying oven $\left(48 \mathrm{~h}\right.$ at $\left.60^{\circ} \mathrm{C}\right)$. Samples of feed and dried excreta were ground through a $0.5 \mathrm{~mm}$ screen and were then analysed for $\mathrm{DM}$ and $\mathrm{Cu}$ content. Dry matter content was determined by oven drying at $100^{\circ} \mathrm{C}$ for $16 \mathrm{~h}$. In order to determine copper content, samples of feed and dried excreta were mineralized in a mixture of nitric acid and perchloric acid (3:1). Mineralization was carried out in an electric aluminium heating block with selectable temperatures (VELP DK 20, VELP Scientifica, Italy), for 4 to $6 \mathrm{~h}$, over a temperature range of 120 to $200^{\circ} \mathrm{C}$. The obtained colourless mineralizate was transferred to $50 \mathrm{~cm}^{3}$ measuring flasks, which were filled up to the mark with deionized water. Copper retention was determined by accounting for the differences between total $\mathrm{Cu}$ in the excreta and feed and adjusted to a DM basis. $\mathrm{Cu}$ intake was counted based at total feed intake by 2 birds for 5 days and described as average daily $\mathrm{Cu}$ intake per 1 bird. $\mathrm{Cu}$ excreted was counted based at total excreta voided by 2 birds for 5 days and described as average daily $\mathrm{Cu}$ excreted per 1 bird. Calculations were made for each replication separately. At the completion of the balance trial the birds were returned to the pens.

On day 56 and 126, blood samples were taken from 7 turkeys of each treatment, and next the birds were sacrificed. Superoxide dismutase (EC 1.1.5.1; SOD) activities in erythrocyte lysates were assayed using kits from Randox Laboratories Ltd. (Crumlin, UK) according to the method described by Woolliams et al. (1983). 
The Randox method uses xanthine and xanthine oxidase to generate superoxide radicals that react with 2-(4-iodophenyl)-3-(4-nitrophenol)-5-phenyltetrazolium (I.N.T.) to form a red formazan dye. The SOD activity is then calculated from the degree of inhibition of this reaction compared to a standard curve of SOD.

On day 56 and 126, the left femoral and tibia bones were excised from all 28 birds, weighed (following the separation of muscles and cartilage), and their volume was measured in distilled water. Bone weight $(\mathrm{w})$ and volume (v) provided a basis for calculating bone specific gravity (w:v). Tibias were next dried for $16 \mathrm{~h}$ at $100^{\circ} \mathrm{C}$, defatted by refluxing with diethyl ether for $6 \mathrm{~h}$, dried in a $100^{\circ} \mathrm{C}$ oven for $16 \mathrm{~h}$, and analysed for ash content, total $\mathrm{Cu}, \mathrm{Ca}$ and $\mathrm{P}$. In order to determine ash content, samples were ashed for $6 \mathrm{~h}$ in an electric furnace at $300^{\circ} \mathrm{C}$, and then at $530-540^{\circ} \mathrm{C}$ until white ash was obtained. The ash was dissolved in a $5 \mathrm{M}$ solution of nitric acid (Suprapur, Merck, Germany). Analytical samples were prepared simultaneously, and reference material SRM 1400 (Bone Ash) was analysed. The obtained mineralizates (non-diluted or diluted) were assayed for the concentrations of $\mathrm{Cu}$ and $\mathrm{Ca}$ by flame atomic absorption spectrometry (acetylene-air flame), as described by Whiteside and Miner (1984), using a Unicam 939 Solar atomic absorption spectrometer (Cambridge, UK) equipped with an Optimus data station, background correction (deuterium discharge lamp) and cathode lamps. Prior to Ca determination, a $10 \%$ aqueous solution of lanthanum chloride was added to all solutions, to ensure the final $\mathrm{La}^{+3}$ concentration of $1 \%$ (Whiteside and Miner, 1984). Total P was determined colormetrically with ammonium molybdate, sodium sulphate and hydroquinone. Conversion of phosphates into phosphoromolybdates in the sulphuric acid environment, with ammonium molybdate, followed by their reduction to phosphoromolybdenum blue with sodium sulphate and hydroquinone. Absorbance was measured using a VIS 6000 spectrophotometer (Krüss-Optronic, Germany) at a wavelength of $610 \mathrm{~nm}$.

\section{Statistical analysis}

All data were analysed statistically by a one-way ANOVA and Duncan's multiple range test, using Statistica 6.0PL software. Replicate means served as experimental units for the statistical analysis. Treatment effects were considered to be significant at $\mathrm{P} \leq 0.05$ or trend at $\mathrm{P}<0.1$.

\section{RESULTS}

$\mathrm{Cu}$ balance. The $\mathrm{Cu}$ content of feed offered to turkeys in group $\mathrm{Cu}-0$ eached $11.35 \mathrm{mg} / \mathrm{kg}$, while in $\mathrm{Cu}$-supplemented diets it was by $14.6-14.8 \mathrm{mg} / \mathrm{kg}(\mathrm{Cu}-\mathrm{SUL}$ 
and $\mathrm{Cu}-\mathrm{SUL} / \mathrm{AA}$ ) to $20.3 \mathrm{mg} / \mathrm{kg}$ (Cu-AA) higher (Table 2). Feed consumption and faeces excreted during the balance test was comparable in all treatments. As expected, $\mathrm{Cu}$ intake in $\mathrm{Cu}$-supplemented groups was significantly $(\mathrm{P} \leq 0.05)$ higher than in group $\mathrm{Cu}-0$ turkeys. In group $\mathrm{Cu}-\mathrm{AA}$ turkeys, $\mathrm{Cu}$ intake was significantly $(\mathrm{P} \leq 0.05)$ higher than in the other groups. Copper retention in $\mathrm{Cu}-\mathrm{O}, \mathrm{Cu}-\mathrm{SUL}$ and $\mathrm{Cu}-$ SUL/AA turkeys was at a similar level (29.1 to 30.1\%). The $\mathrm{Cu}$ retention coefficient of $\mathrm{Cu}-\mathrm{AA}$ turkeys was significantly $(\mathrm{P} \leq 0.05)$ higher than in birds administered $\mathrm{Cu}-$ SUL, Cu-SUL/AA and $\mathrm{Cu}-0$. The $\mathrm{Cu}$ unsupplemented basal diet contained 11.3 $\mathrm{mg} \mathrm{Cu} / \mathrm{kg}$ and further $\mathrm{Cu}$ supplementation from inorganic and/or organic sources significantly increased $(\mathrm{P} \leq 0.05) \mathrm{Cu}$-excretion (from 808 to $1915-2164 \mathrm{mg}$ per bird).

Table 2. The effects of copper source on $\mathrm{Cu}$ balance in male turkeys from 25 to $29 \mathrm{~d}$ of age ${ }^{1}$

\begin{tabular}{|c|c|c|c|c|c|}
\hline \multirow{2}{*}{ Item } & \multicolumn{4}{|c|}{$\mathrm{Cu}_{\text {source }}^{2}$} & \multirow{2}{*}{ SEM } \\
\hline & $\mathrm{Cu}-0$ & $\mathrm{Cu}-\mathrm{SUL}$ & $\mathrm{Cu}-\mathrm{SUL} / \mathrm{AA}$ & $\mathrm{Cu}-\mathrm{AA}$ & \\
\hline \multicolumn{6}{|l|}{ Feed } \\
\hline $\mathrm{Cu}$ content in feed, $\mu \mathrm{g} / \mathrm{g}$ & 11.35 & 26.20 & 26.00 & 31.68 & - \\
\hline feed intake, g/day per bird & 101.3 & 107.9 & 105.4 & 104.0 & 1.1 \\
\hline $\mathrm{Cu}$ intake, $\mu \mathrm{g}$ & $1150^{\mathrm{A}}$ & $2827^{\mathrm{B}}$ & $2741^{\mathrm{B}}$ & $3294^{\mathrm{C}}$ & 187 \\
\hline \multicolumn{6}{|l|}{ Faeces, after drying } \\
\hline $\mathrm{Cu}$ content, $\mu \mathrm{g} / \mathrm{g}$ & 28.30 & 66.00 & 65.17 & 75.78 & - \\
\hline faeces excreted, g/day/bird & 28.6 & 30.4 & 29.4 & 28.6 & 0.4 \\
\hline $\mathrm{Cu}$ excreted, $\mu \mathrm{g}$ & $808^{\mathrm{A}}$ & $2004^{\mathrm{B}}$ & $1915^{\mathrm{B}}$ & $2164^{C}$ & 124 \\
\hline Apparent $\mathrm{Cu}$ retention, $\%$ of $\mathrm{Cu}$ intake & $29.6^{\mathrm{A}}$ & $29.1^{\mathrm{A}}$ & $30.1^{\mathrm{A}}$ & $34.3^{\mathrm{B}}$ & 0.8 \\
\hline \multicolumn{6}{|c|}{$\begin{array}{l}{ }^{1} \text { data represent mean values of five replicate; }{ }^{2} \text { experimental diets: } \mathrm{Cu}-0 \text { - wheat based feed without } \\
\text { copper supplements and experimental diets containing } 20 \mathrm{mg} / \mathrm{kg} \text { of copper from } \mathrm{CuSO}{ }_{4}(\mathrm{Cu}-\mathrm{SUL}) \\
\text { or copper amino acid chelate }(\mathrm{Cu}-\mathrm{AA}) \text {, or both source }(10 \mathrm{mg}+10 \mathrm{mg} \text {; } \mathrm{Cu}-\mathrm{SUL} / \mathrm{AA}) \\
\text { means within the same line with no common superscripts differ significantly: }{ }^{\mathrm{A}-\mathrm{B}} \mathrm{P} \leq 0.05 \text { as a result } \\
\text { of a Duncan means comparison }\end{array}$} \\
\hline
\end{tabular}

Turkey growth, feed conversion and mortality. The response to birds to dietary copper varied widely (Table 3 ). At 28 days of age, the body weight of turkeys fed a diet with $\mathrm{Cu}$-SUL or $\mathrm{Cu}-\mathrm{AA}$ was significantly $(\mathrm{P} \leq 0.05)$ higher than the body weight of control group turkeys $(\mathrm{Cu}-0)$ and those fed a diet with $\mathrm{Cu}$ SUL/AA. At 56 days of age, only the body weight of birds given a diet with $\mathrm{Cu}-\mathrm{AA}$ was significantly $(\mathrm{P} \leq 0.05)$ higher than $\mathrm{Cu}-0$ and $\mathrm{Cu}-\mathrm{SUL} / \mathrm{AA}$ turkeys. On day 84 , similarly as on day 28 , the body weight of group Cu-AA turkeys was significantly $(\mathrm{P} \leq 0.05)$ higher than the body weight of turkeys in groups $\mathrm{Cu}$ SUL/AA and $\mathrm{Cu}-0$. On day 84 , the body weight of turkeys in group $\mathrm{Cu}-\mathrm{SUL}$ was significantly $(\mathrm{P} \leq 0.05)$ higher than in $\mathrm{Cu}-0$, but tended $(\mathrm{P}<0.1)$ to lower than in group $\mathrm{Cu}-\mathrm{AA}$. At the end of rearing (day 126), the body weights of turkeys in particular treatments were similar. 
Table 3. Body weight (BW), feed conversion ratio (FCR) and mortality of turkeys raised to 18 weeks of age ${ }^{1}$

\begin{tabular}{|c|c|c|c|c|c|}
\hline \multirow{2}{*}{ Item } & \multicolumn{4}{|c|}{$\mathrm{Cu}$ source ${ }^{2}$} & \multirow{2}{*}{ SEM } \\
\hline & $\mathrm{Cu}-0$ & $\mathrm{Cu}-\mathrm{SUL}$ & $\mathrm{Cu}-\mathrm{SUL} / \mathrm{AA}$ & Cu-AA & \\
\hline \multicolumn{6}{|c|}{ Body weight, kg/bird } \\
\hline at 28 & $1.136^{\mathrm{A}}$ & $1.174^{\mathrm{B}}$ & $1.137^{\mathrm{A}}$ & $1.178^{\mathrm{B}}$ & 0.004 \\
\hline at 56 & $4.830^{\mathrm{A}}$ & $4.875^{\mathrm{AB}}$ & $4.821^{\mathrm{A}}$ & $4.917^{\mathrm{B}}$ & 0.014 \\
\hline at 84 & $9.585^{\mathrm{A}}$ & $9.741^{\mathrm{BCa}}$ & $9.661^{\mathrm{AC}}$ & $9.864^{\mathrm{Bb}}$ & 0.027 \\
\hline at 126 & 17.142 & 17.126 & 17.165 & 17.142 & 0.051 \\
\hline \multicolumn{6}{|l|}{$F C R, \mathrm{~kg} / \mathrm{kg}$} \\
\hline 1 to $28 \mathrm{~d}$ & $1.447^{\mathrm{b}}$ & $1.414^{\mathrm{a}}$ & $1.416^{\mathrm{a}}$ & $1.421^{\mathrm{ab}}$ & 0.006 \\
\hline 1 to $56 \mathrm{~d}$ & 1.772 & 1.753 & 1.762 & 1.744 & 0.005 \\
\hline 1 to $84 \mathrm{~d}$ & $2.121^{\mathrm{B}}$ & $2.053^{\mathrm{A}}$ & $2.043^{\mathrm{A}}$ & $2.013^{\mathrm{A}}$ & 0.012 \\
\hline 1 to $126 \mathrm{~d}$ & 2.632 & 2.603 & 2.575 & 2.597 & 0.012 \\
\hline \multicolumn{6}{|l|}{ Mortality, $\%$} \\
\hline 1 to $28 \mathrm{~d}$ & 1.4 & - & 0.46 & - & \\
\hline 1 to $126 \mathrm{~d}$ & 2.79 & 2.30 & 4.17 & 2.76 & \\
\hline
\end{tabular}

Over a period of 1 to 28 days, a tendency towards a lower $(\mathrm{P}<0.1)$ feed conversion ratio (FCR) was noted in groups $\mathrm{Cu}-\mathrm{SUL}$ and $\mathrm{Cu}-\mathrm{SUL} / \mathrm{AA}$, in comparison with the control group. During a period of 1 to 56 days, FCR were generally not affected by dietary treatment. Throughout a period of 1 to 84 days, FCR was significantly $(\mathrm{P} \leq 0.05)$ lower in turkeys fed a $\mathrm{Cu}$-supplemented diet than in group $\mathrm{Cu}-0$. The $\mathrm{FCR}$ estimated for the entire rearing period (1-126 days) was at a comparable level in all treatments, irrespective of the copper source in the diet.

The health condition of turkeys was generally good over the experimental period (Table 3). Until day 28, the mortality rate in treatments varied from 0.46 to $1.4 \%$, and throughout the rearing period, i.e. 126 days, it ranged from 2.3 to $4.2 \%$. Between 14 and 18 weeks of age, mortality due to aortic rupture was diagnosed in 5 turkeys, including 1 bird in group $\mathrm{Cu}-\mathrm{SUL}$ and 2 birds in groups $\mathrm{Cu}-\mathrm{AA}$ and $\mathrm{Cu}-\mathrm{SUL} / \mathrm{AA}$. There was no relationship between the causes of mortality and the copper source in feed.

Plasma superoxide dismutase activity. Average activity of superoxide dismutase in blood plasma of turkeys of different groups was in small degree differentiate and difference between dietary treatments was statistically nonsignificant (Figure 1).

Bone mineral content. Femur relative weight and specific gravity were unaffected $(\mathrm{P}>0.1)$ by dietary treatments on days 56 and 126 (Figure 2). Tibia specific gravity, ash content and the concentrations of major mineral elements $(\mathrm{Ca}$ and $\mathrm{P})$ were also unaffected $(\mathrm{P}>0.1)$ by dietary treatments (Table 4$)$. At the age of 56 days, a tendency towards a higher tibia relative weight and tibia $\mathrm{Cu}$ 


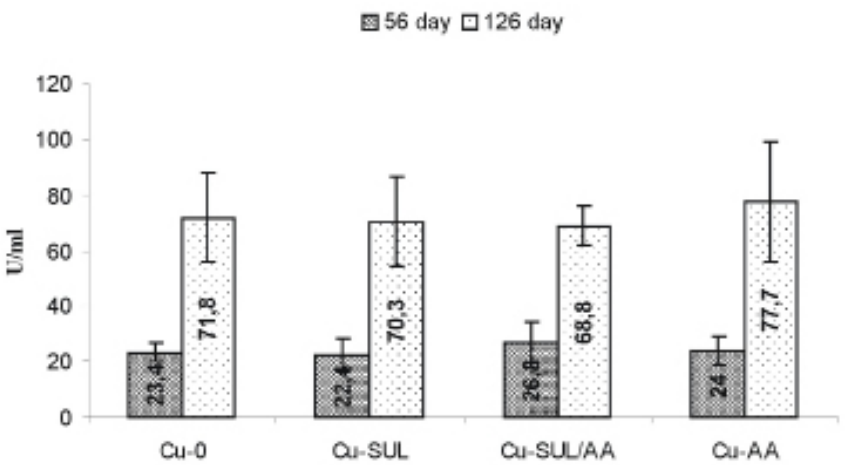

Figure 1. Superoxide dismutase (SOD) activity in blood plasma of turkeys at 56 days and 126 days of age, $\mathrm{U} / \mathrm{ml}^{1} ;{ }^{1}$ data represent mean values of seven turkeys per treatment

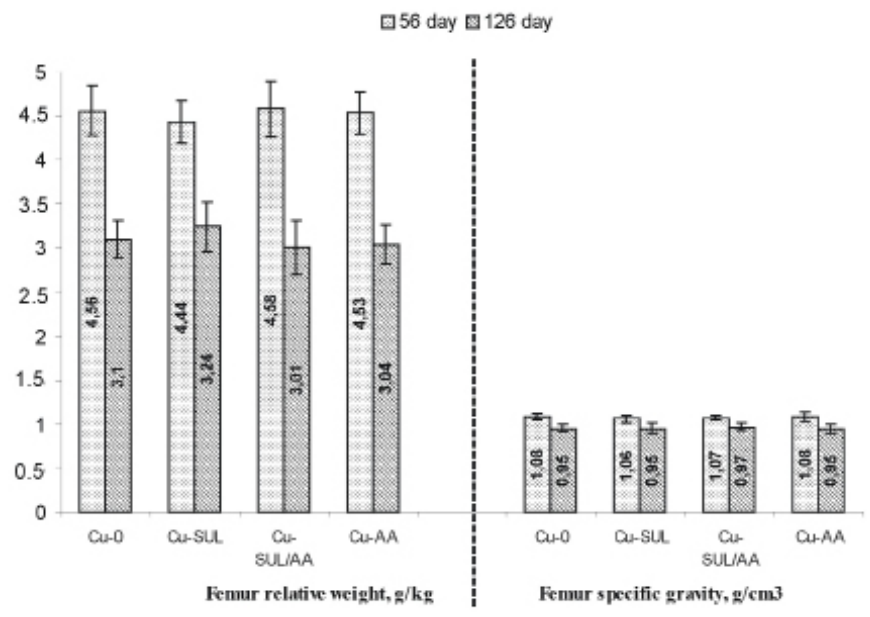

Figure 2. Femur relative weight and specific gravity of turkeys at 56 and 126 days of age ${ }^{1} ;{ }^{1}$ data represent mean values of seven turkeys per treatment

concentration $(\mathrm{P}<0.1)$ was noted in turkeys fed a $\mathrm{Cu}-\mathrm{AA}$ supplemented diet, compared to $\mathrm{Cu}-\mathrm{SUL}$ and $\mathrm{Cu}-0$ treatment. Such a rising trend (by $25 \% ; \mathrm{P}<0.1$ ) in tibia $\mathrm{Cu}$ concentration was also reported in group $\mathrm{Cu}-\mathrm{AA}$ turkeys on day 126 , compared with turkeys fed inorganic $\mathrm{Cu}$, i.e. $\mathrm{CuSO}_{4}(\mathrm{Cu}-\mathrm{SUL})$. The addition of 20 $\mathrm{ppm}$ copper in the form of $\mathrm{Cu}-\mathrm{SUL}$ to diets for turkeys had no effect on tibia $\mathrm{Cu}$ concentration. At the age of 126 days, dietary supplementation with $\mathrm{Cu}$-SUL/AA or $\mathrm{Cu}$-AA significantly increased $(\mathrm{P} \leq 0.05)$ the concentration of $\mathrm{Cu}$ in tibia bone, compared to the control treatment. 
Table 4. Characteristics of tibia bone of turkeys at 56 and 126 days of age ${ }^{1}$

\begin{tabular}{|c|c|c|c|c|c|}
\hline \multirow{2}{*}{ Item } & \multicolumn{4}{|c|}{$\mathrm{Cu}_{\mathrm{source}}{ }^{2}$} & \multirow{2}{*}{ SEM } \\
\hline & $\mathrm{Cu}-0$ & $\mathrm{Cu}-\mathrm{SUL}$ & $\mathrm{Cu}-\mathrm{SUL} / \mathrm{AA}$ & $\mathrm{Cu}-\mathrm{AA}$ & \\
\hline \multicolumn{6}{|l|}{56 days } \\
\hline tibia relative weight, $\mathrm{g} / \mathrm{kg} \mathrm{BW}$ & $5.80^{\mathrm{a}}$ & $5.81^{\mathrm{a}}$ & $5.96^{\mathrm{ab}}$ & $6.26^{\mathrm{b}}$ & 0.088 \\
\hline tibia specific gravity, $\mathrm{g} / \mathrm{cm}^{3}$ & 1.17 & 1.18 & 1.18 & 1.19 & 0.006 \\
\hline tibia ash, $\%$ & 45.47 & 45.88 & 46.54 & 46.56 & 0.322 \\
\hline $\mathrm{Cu}$ content, $\mathrm{mg} / \mathrm{kg} \mathrm{DM}$ & $1.05^{\mathrm{a}}$ & $1.07^{\mathrm{a}}$ & 1.12 & $1.22^{\mathrm{b}}$ & 0.032 \\
\hline Ca content, mg/kg DM & 184.1 & 187.9 & 190.0 & 193.0 & 2.176 \\
\hline P content, mg/kg DM & 86.39 & 87.11 & 88.50 & 88.82 & 0.990 \\
\hline \multicolumn{6}{|l|}{126 days } \\
\hline tibia relative weight, $\mathrm{g} / \mathrm{kg} \mathrm{BW}$ & 4.28 & 4.40 & 4.01 & 4.39 & 0.076 \\
\hline tibia specific gravity, $\mathrm{g} / \mathrm{cm}^{3}$ & 1.01 & 1.02 & 0.99 & 1.01 & 0.005 \\
\hline tibia ash, $\%$ & 63.00 & 63.29 & 63.39 & 62.97 & 0.163 \\
\hline $\mathrm{Cu}$ content, $\mathrm{mg} / \mathrm{kg} \mathrm{DM}$ & $0.257^{\mathrm{A}}$ & $0.317^{\mathrm{a}}$ & $0.341^{\mathrm{B}}$ & $0.395^{\mathrm{Bb}}$ & 0.016 \\
\hline Ca content, mg/kg DM & 241.5 & 245.1 & 240.2 & 238.1 & 1.191 \\
\hline $\mathrm{P}$ content, $\mathrm{mg} / \mathrm{kg} \mathrm{DM}$ & 113.6 & 115.8 & 115.1 & 113.8 & 0.974 \\
\hline
\end{tabular}

\section{DISCUSSION}

In earlier experiments of other authors (Baker et al., 1991; Mondal et al., 2007) dietary $\mathrm{Cu}$ in organic form, including $\mathrm{Cu}$-lysine, $\mathrm{Cu}$-methionine and $\mathrm{Cu}$-proteinate, was absorbed to the same or to a higher degree than $\mathrm{Cu}$ in the form of cupric sulphate. Paik et al. (1999) reported that $\mathrm{Cu}$ from a $\mathrm{Cu}$-methionine complex was better absorbed and accumulated to a higher degree in the breast muscles and to a lower degree in the liver of chickens than $\mathrm{Cu}$ from copper sulphate. In our study $\mathrm{Cu}$ unsupplemented basal diet contained $11.3 \mathrm{mg} \mathrm{Cu} / \mathrm{kg}$ was enough for turkeys. The increase of $\mathrm{Cu}$ content in diet to $26 \mathrm{mg} / \mathrm{kg}$ (Cu-SUL and Cu-SUL/AA) had no effect on apparent $\mathrm{Cu}$ retention in turkeys. Further $\mathrm{Cu}$ supplementation from inorganic and/or organic sources increased the $\mathrm{Cu}$-excretion (from 808 to 1915$2164 \mathrm{mg}$ per bird) and may cause additional environmental problems.

Studies with broiler chickens indicated that copper in organic form was more effective in stimulating growth at lower concentrations than copper sulphate (Pesti and Bakali, 1996; Ewing et al., 1998). In this experiment the $\mathrm{Cu}$ unsupplemented basal diet contained $11.3 \mathrm{mg} \mathrm{Cu} / \mathrm{kg}$ was enough for turkeys and confirm the $\mathrm{Cu}-$ requirements for growing/fattening turkeys given by scientific bodies (e.g., NRC, INRA, GfE). Further Cu-supplementations from inorganic and/or organic sources did not significantly improve turkeys performance and health. Other authors (Guo et al., 2001; Banks et al., 2004a) reported also that copper source did not affect broiler performance. 
The concentration of $\mathrm{Cu}$ in body tissues of mammals varies greatly with species and age. It is high in the livers and kidneys of cattle and sheep, and low in the same organs of swine and chickens (Doyle and Spaulding, 1978). Bones are tissues of intermediate $\mathrm{Cu}$ concentration and, like the liver and kidney, are particularly responsive to changes in $\mathrm{Cu}$ intake (Underwood, 1977). In the present study, tibia $\mathrm{Cu}$ concentration was found an increasing trend $(\mathrm{P}<0.1)$ in 56-dayand 126-day-old turkeys fed a $\mathrm{Cu}$-AA chelate supplemented diet, compared to birds given a diet with $\mathrm{Cu}$-sulphate. In an experiment performed by Banks et al. (2004b), bone mineralization results indicated that chickens fed diet with $\mathrm{Cu}-$ lysinate had the greatest $(\mathrm{P} \leq 0.05)$ tibia and toe ash percentages and weights as compared with birds fed $\mathrm{Cu}$-citrate or $\mathrm{Cu}$-sulphate diets. Our results show that the tibia major mineral concentration $(\mathrm{Ca}$ and $\mathrm{P})$ were unaffected $(\mathrm{P}>0.1)$ by dietary treatments both at days 56 and 126 of the experiment. Similarly, Mondal et al. (2007) reported no impact of dietary copper source on major mineral balance and plasma concentrations of such elements as $\mathrm{Ca}, \mathrm{P}$ and $\mathrm{Mg}$ in broilers.

\section{CONCLUSIONS}

In conclusion, the results of the present study confirm recommendations of scientific bodies concerning Cu-requirements of growing/fattening turkeys (e.g., NRC, INRA, GfE). The $\mathrm{Cu}$ unsupplemented basal diet contained $11.3 \mathrm{mg} \mathrm{Cu} /$ $\mathrm{kg}$ and further $\mathrm{Cu}$-supplementations from inorganic and/or organic sources did not significantly improve turkeys performance and health. Plasma superoxide dismutase activity, physico-chemical properties of bone and the concentrations of $\mathrm{Ca}$ and $\mathrm{P}$ in the tibia bone were generally not affected by the copper source. There is no need for additional supplementation of inorganic or organic copper. Further $\mathrm{Cu}$ supplementation increase the $\mathrm{Cu}$-excretion (from 808 to 1915-2164 mg per animal) and may cause additional environmental problems.

\section{REFERENCES}

Aoyagi S., Baker D.H., 1993. Bioavailability of copper in analytical-grade and feed-grade inorganic copper sources when fed to provide copper at levels below the chick's requirement. Poultry Sci. $72,1075-1083$

Baker D.H., Odle J., Funk M.A., Wieland T.M., 1991. Research note: bioavailability of copper in cupric oxide, cuprous oxide and in copper lysine complex. Poultry Sci. 70, 177-179

Banks K.M., Thompson K.L., Jaynes P., Applegate T.J., 2004a. The effects of copper on the efficacy of phytase, growth, and phosphorus retention in broiler chicks. Poultry Sci. 83, 1335-1341 
Banks K.M., Thompson K.L., Rush J.K., Applegate T.J., 2004b. Effects of copper source on phosphorus retention in broiler chicks and laying hens. Poultry Sci. 83, 990-996

B.U.T. Commercial Performance Goals, 2002. British United Turkeys Ltd. 5th Edition. Waren Hall Broughton, Chester (England). Available at: http://www.aviagen.com/home.aspx?siteId=8

Doyle J.J., Spaulding J.E., 1978. Toxic and essential elements in meat. J. Anim. Sci. 47, 398-419

Du Z., Hemken R.W., Jackson J.A., Trammell D.S., 1996. Utilization of copper in copper proteinate, copper lysine, and cupric sulfate using the rat as an experimental model. J. Anim. Sci. 74, 16571663

Ewing H.P., Pesti G.M., Bakalli R.I., Menten J.F., 1998. Studies on the feeding of cupric sulfate pentahydrate, cupric citrate, and copper oxychloride to broiler chickens. Poultry Sci. 77, 445448

Guo R., Henry P.R., Holwerda R.A., Cao J., Littell R.C., Miles R.D., Ammerman C.B., 2001. Chemical characteristics and relative bioavailability of supplemental organic copper sources for poultry. J. Anim. Sci. 79, 1132-1141

Hemken R.W., Clark T.W., Du Z., 1993. Copper: its role in animal nutrition. In: T.P. Lyons (Editor). Biotechnology in the Feed Industry. Alltech Technical Publications. Nicholasville, KY (USA), pp. 35-39

Hurwitz S., Bar A., 1965. Absorption of calcium and phosphorus along the gastrointestinal tract of the laying fowl as influenced by dietary calcium and egg shell formation. J. Nutr. 86, 433-438

McDowell L.R., 1992. Copper and molybdenum. In: Minerals in Animal and Human Nutrition. Academic Press Inc. San Diego, CA, pp. 176-204

Mondal M.K., Das T.K., Biswas P., Samanta C.C., Bairagi B., 2007. Influence of dietary inorganic and organic copper salt and level of soybean oil on plasma lipids, metabolites and mineral balance of broiler chickens. Anim. Feed Sci. Tech. 139, 212-233

NRC, 1994. Nutritional Requirements of Poultry. 9th revised Edition. National Academy Press. Washington, DC

Paik I.K., Seo S.H., Um J.S., Chang M.B., Lee B.H., 1999. Effects of supplementary copper-chelate on the performance and cholesterol level in plasma and breast muscle of broiler chickens. AsianAustr. J. Anim. Sci. 12, 794-798

Pesti G.M., Bakalii R.I., 1996. Studies on the feeding of cupric sulfate pentahydrate and cupric citrate to broiler chickens. Poultry Sci. 75, 1086-1091

Savage J.E., Bird D.W., Reynolds G., O’Dell B.L., 1966. Comparison of copper deficiency and lathyrism in turkey poults. J. Nutr. $88,15-25$

SCAN, 2003. Opinion of the Scientific Committee for Animal Nutrition on the Use of Copper in Feedingstuffs. http://ec.europa.eu/food/fs/sc/scan/index_en.html

Underwood E.J., 1977. Copper. In: Trace Elements in Human and Animal Nutrition. 4th Edition. Academic Press. New York, NY

Whiteside P., Miner B., 1984. Pye Unicam Atomic Absorption Data Book. Pye Unicam LTD. Cambridge (England)

Woolliams J.A., Wiener G., Anderson P.H., McMurray C.H., 1983. Variation in the activities of glutathione peroxidase and superoxide dismutase in the concentration of copper in the blood in various breed crosses of sheep. Res. Vet. Sci. 34, 253-256 